\title{
PEMANFAATAN INSTAGRAM SEBAGAI MEDIA KOMUNIKASI PEMASARAN DALAM MENINGKATKAN PENJUALAN (Studi Kasus pada Akun Instagram @ Kaosdisablon di CV. Purwa Satya)
}

\author{
Daisy Ade Riany Diem1, Widiya Yulianti2
}

${ }^{1,2}$ Dosen Manajemen Industri, STT Wastukancana Purwakarta daisyard@stt-wastukancana.ac.id

\begin{abstract}
Abstrak
Kemunculan teknologi komunikasi (internet) mampu menghadirkan berbagai perubahan dalam kehidupan sosial manusia. Dengan munculnya alat komunikasi seperti smartphone serta media sosial memudahkan kita dalam berkomunikasi dan berbagi informasi dengan siapa saja dan dimana saja. Komuniksi pemasaran merupakan upaya untuk menjadikan seluruh kegiatan pemasaran dan promosi perusahaan dapat menghasilkan citra atau image yang bersifat satu atau konsisten bagi konsumen. CV. Purwa Satya merupakan salah satu usaha di bidang penjualan kaos dan jasa sablon digital yang menggunakan media sosial instagram sebagai media peasaran online dengan nama akun@kaosdisablon. Penelitan ini bertujuan untuk mengetahui bagaimana pemanfaatan Instagram sebagai media komunikasi pemasaran dan dampaknya terhadap penjualan. Jenis penelitian ini adalah studi kasus dengan metode deskriptif kuantitatif. Teknik wawancara yang dilakukan yaitu wawancara mendalam (in-depth interview), observasi dan dokumentasi pada akun Instagram @kaosdisablon serta didukung oleh data penunjang berupa datadata penjualan kaosdisablon selama 1 tahun dari periode Juni 2018-Mei 2019. Hasil penelitian ini diketahui bahwa Kaosdisablon memanfaatkan instagram sebagai media pemasaran online-nya dengan menentukan tujuan komunikasi pemasaran melalui model komunikasi pemasaran modern, memanfaatkan fitur yang ada di Instagram, serta mengenali sifat konsumen untuk pemeliharaan media pemasaran yang tepat. Kaosdisablon juga memanfaatkan feature terbaru Instagram yaitu dengan mengubah ke akun bisnis untuk memfokuskan target dan rutin memanfaatkan feature iklan setiap hari. Adapun yang dirasakan oleh Kaosdisablon tentang pemanfaatan Instagram sebagai media komunikasi pemasaran dalam meningkatkan penjualan dimana 88,47\% pembeli mengetahui informasi Kaosdisablon dari Instagram. Hal tersebut terjadi karena Instagram memudahkan customer dalam mencari informasi dan melakukan proses pembelian produk dari Kaosdisablon.
\end{abstract}

Kata kunci : instagram, sosial media, komunikasi pemasaran, penjualan

\section{Pendahuluan}

Teknologi memberikan kemudahan bagi manusia untuk menyelesaikan pekerjaannya sehingga masyarakat dapat menjadi sangat kreatif dalam memanfaatkan kecanggihan teknologi dan informasi dengan membuat karya-karya baru tak terkecuali dalam berkomunikasi. Munculnya alat komunikasi seperti smartphone memudahkan kita dalam berkomunikasi dan berbagi informasi dengan siapa saja dan dimana saja. Aplikasi-aplikasi yang ada di smartphone dapat dimanfaatkan sebagai media untuk bertukar informasi dan berkomunikasi. Hal inilah yang dapat dimanfaatkan dalam melakukan komunikasi pemasaran.

Menurut Morrisan (2010) komunikasi pemasaran merupakan upaya untuk menjadikan seluruh kegiatan pemasaran dan promosi perusahaan dalam menghasilkan citra atau image yang bersifatsatu atau konsisten bagi konsumen. Komunikasi pemasaran juga dapat mengembangkan kesadaran konsumen terhadap produk/jasa yang ditawarkan perusahaan, sehingga konsumen dapat mengenal produk/jasa yang ditawarkan dan membuat konsumen menjadi tertarik dan melakukan transaksi pembelian. Komunikasi pemasaran berperan untuk mengkomunikasikan dan memperlihatkan value yang ditawarkan perusahaan kepada konsumennya, sehingga konsumen dapat mempelajari tentang apa, merk apa, siapa yang memproduksi, apa keunggulannya, cocok dikonsumsi oleh siapa, dan bagaimana cara memperolehnya. Selain itu, komunikasi pemasaran juga berkontribusi dalam ekuitas merek dengan menanamkan merek di dalam ingatan konsumen. Tidak dapat dipungkiri bahwa komunikasi pemasaran juga membutuhkan media komunikasi dalam proses komunikasi pemasaran, salah satunya yaitu melalui media sosial (Priansa, 2017). Arus pertukaran informasi kini menjadi semakin 
cepat karena semakin berkembangnya penggunaan internet yang semakin pesat. Hal inilah yang membuat manusia lebih cenderung berkomunikasi melalui internet karena memudahkan penggunanya untuk saling berkomunikasi tanpa ada batasan. Dengan kemudahan inilah yang membuat jutaan orang di dunia memanfaatkan internet sebagai media komunikasi sehingga terbentuknya situs media sosial.

Berdasarkan uraian diatas, peneliti ingin melihat bagaimana strategi yang dilakukan pada usaha-usaha kecil menengah (UKM) dalam memanfaatkan media sosial instagram khususnya di CV. Purwa Satya yang merupakan salah satu perusahaan yang baru merintis di bidang penjualan kaos dan jasa sablon digital di Purwakarta. Dengan produk yang dihasilkan, CV. Purwa Satya mempunyai peluang yang sangat besar untuk memasarkan produknya secara langsung maupun secara online terlebih khususnya pada instagram. Adapun brand atau merk yang diperkenalkan kepada masyarakat saat ini dikenal dengan nama Kaosdisablon yang merupakan salah satu strategi dalam pemasaran agar mudah dikenal dan diingat oleh orang. Kaosdisablon sendiri merupakan kependekan dari Kaos Digital Sablon. Akun instagram yang bermana @ kaosdisablon telah memiliki lebih dari 4,2 K followers dan merupakan salah satu industri kreatif di bidang penjualan kaos dan jasa sablon digital yang memanfaatkan media instagram sebagai sarana komunikasi pemasaran produknya secara online.

\section{Tujuan Penelitian}

Tujuan penelitian ini adalah untuk mendeskripsikan secara kualitatif pemanfaatan Instagram pada akun @kaosdisablon yang dimiliki oleh CV. Purwa Satya sebagai media komunikasi pemasaran dan dampaknya terhadap penjualan.

\section{Tinjauan Pustaka}

\subsection{Komunikasi Pemasaran}

Kegiatan komunikasi pemasaran merupakan rangkaian kegiatan untuk mewujudkan suatu produk, jasa, ide, dengan menggunakan bauran pemasaran yaitu: iklan, penjualan tatap muka, promosi penjualan, hubungan masyarakat dan publisitas serta pemasaran langsung (Purba et. al., 2006).

Marketing communication atau komunikasi pemasaran dapat didefinisikan sebagai kegiatan pemasaran dengan menggunakan teknik-teknik komunikasi yang bertujuan untuk memberikan informasi kepada khalayak agar tujuan perusahaan tercapai, yaitu terjadinya peningkatan pendapat atas penggunaan jasa atau pembelian produk yang ditawarkan (Kennedy dan Soemanagara, 2006:5).
Strategi pemasaran merupakan desain perencanaan untuk mempengaruhi pemikiran dalam mencapai tujuan. Tujuan dari strategi pemasaran ini mengarah pada peningkatan kemungkinan atau frekuensi perilaku konsumen seperti peningkatan untuk berkunjung ke suatu toko maupun untuk membeli suatu produk tertentu (Setiadi, 2008).

\subsection{Komunikasi Pemasaran Online}

Di era globalisasi sekarang ini, internet menawarkan peluang untuk melakukan penjualan produk kebutuhan hidup sehari-hari secara langsung kepada pelanggan yang berada pada pasar konsumsi (consumer market) atau konsumen pada pasar industri (business-to- business market). Penjualan barang dan jasa secara langsung (direct selling) melalui internet dinamakan dengan istilah ecommerce. Banyak perusahaan atau bisnis-bisnis kecil saat ini yang menyediakan fasilitas penjualan produknya secara online selain melalui cara konvensional yaitu melalui jaringan distribusi pemasaran, namun dewasa ini tidak sedikit perusahaan yang hanya menjual produknya melalui internet atau media sosial.

Terdapat beberapa alasan mengapa perusahaan menjalankan bisnis dengan menggunakan fasilitas e-commerce (Morissan, 2010), yaitu:

1) Dapat menjangkau audiences di seluruh dunia.

2) Dapat melakukan komunikasi interaktif dengan biaya yang efisien.

3) Dapat menjangkau target konsumen tertentu.

4) Lebih mudah menyampaikan perubahan informasi seperti perubahan harga atau informasi lainnya.

5) Meningkatkan pelayanan kepada pelanggan karena tersedia akses selama 24 jam, tujuh hari seminggu.

6) Mendapatkan umpan balik segera dari konsumen.

7) Merupakan saluran distribusi alternatif.

8) Menyediakan biaya penyebaran informasi merek yang efektif dan efisien.

\subsection{Pemilihan Media Pemasaran}

Media penyampai pesan memegang peranan penting dalam proses komunikasi. Tanpa media, pesan tidak akan sampai pada kelompok audiens yang diinginkan. Oleh karena itu, pemilihan media yang tepat akan sangat menentukan apakah pesan yang ingin disampaikan pada kelompok sasaran akan sampai atau tidak (Sutisna, 2001). Media pemasaran meliputi segenap perangkat yang dapat memuat atau membawa pesan-pesan penjualan kepada para calon pembeli.

Pemilihan media yang tepat untuk memasarkan produk dalam rangka membuat pelanggan menjadi tahu, paham, menentukan sikap, hingga melakukan pembelian adalah suatu langkah penting dalam kegiatan pemasaran. Dalam pemasran, komunikator (produsen) dapat memilih satu mau pun kedua media untuk menyampaikan pesan yang ingin 
mereka sampaikan. Media-media tersebut ialah media lini atas (above-the-line) maupun media lini bawah (below-the-line). Media lini atas (above-theline) ialah pemasaran yang menggunakan media primer seperti media elektronik maupun media cetak. Penggunaan media lini atas memiliki kelebihan dalam menjangkau jumlah audience yang besar, namun hal ini juga membuat biaya yang harus dikeluarkan sebuah perusahaan untuk pemesaran bertambah.

Sedangkan media lainnya ialah media lini bawah (below-the-line), media ini adalah mediamedia minor yang digunakan untuk memasarkan produk. Meskipun dianggap menjadi media minor, namun berpemasaran pada media lini bawah juga memiliki peranan penting dalam suatu komunikasi pemasaran. Hal ini disebabkan karena media lini bawah dalam hal-hal tertentu bisa menjadi lebih efektif, tergantung bentuk memasarkan dan mengkomunikasikan yang hendak dilakukan oleh perusaaan (Jefkins, 1997).

\subsection{Media Sosial Instagram}

Instagram sebagai jejaring sosial yang berbasis internet sekaligus jejaring sosial untuk berbagi cerita via gambar digital. Para pengguna gadget kerap kali menggunakan jejaring ini untuk langsung berbagi hasil pengambilan gambar langsung (Sulianta, 2015). Instagram merupakan media komunikasi yang dapat dimanfaatkan sebagai media pemasaran dengan meng-upload produk atau jasa yang ditawarkan dengan mengemasnya dan memanfaatkan beberapa fitur instagram yang mampu memberikan keuntungan bagi perusaaan.

Seorang pengusaha apabila memanfaatkan instagram sebagai media pemasaran akan memberikan beberapa keuntungan. Kemudahan instagram sebagai media yang tidak berbayar untuk melakukan sebuah pemasaran mampu memberikan keuntungan yang besar dengan memanfaatkan fitur dan jasa endorser. Followers atau pengikut dalam instagram menjadi sebuah keuntungan tersendiri bagi penggunanya.

Akun pribadi yang memiliki followers yang banyak mampu memberikan keuntungan tersendiri untuk dirinya, namun dengan mendapatkan followers asli (bukan followers robot), begitu pula dengan akun pemasaran produk, namun perbedaan antara akun pribadi dan penjualan adalah akun penjualan hanya mem-posting produk yang ditawarkan, mengutamakan kejujuran pada keterangan foto (caption), memberikan \#hastag sebagai kunci dalam memudahkan konsumen untuk menemukan apa yang dipasarkan.

Instagram memiliki beberapa fitur, dan setiap dari fitur tersebut meimiliki fungsi masingmasing yang berbeda dengan jejaring sosial lainnya, yaitu:

a. Followers (Pengikut)

b. Upload Foto (Mengunggah Foto) c. Kamera

d. Efek Foto

e. Arroba

f. Caption (Judul Foto)

g. Geotagging (Menandai Tempat)

h. Like (Suka)

i. Populer (Explore)

Dalam penelitian Banjaransari (2018), Instagram seolah-olah seperti miniaturisasi toko secara fisik. Instagram memfasilitasi dan meleburkan sekat antara batas ruang yang telah tereliminasi, karena teknologi aplikasi Instagram justru memudahkan seseorang mengakses informasi secara virtual serta Instagram yang mampu dalam meningkatkan kepercayaan pelanggannya.

Selain itu, promosi produk melalui postingan di Instagram berupa foto dan video menarik perhatian generasi $\mathrm{Z}$ pengguna Instagram yang pada akhirnya generasi $\mathrm{Z}$ akan mencapai kesadaran merek (Sa'diya, 2017).

\section{Metodologi Penelitian}

Penelitian ini merupakan penelitian deskriptif dengan pendekatan kualitatif. Data primer diperoleh melalui in-depth-interview dengan narasumber yaitu CV. Purwa Satya yang merupakan pemilik akun@kaosdisablon, karyawan, reseller dan pengguna Instagram sekaligus pelanggan dari @kaosdisablon.

\section{Hasil dan Pembahasan}

CV. Purwa Satya merupakan perusahaan yang bergerak di bidang perdagangan barang dan jasa. Ketika pertama didirikan perusahaan ini melayani segala macam pengadaan pakaian jadi seperti kaos, kemeja, celana, polo shirt, jaket, almamater dan lain sebagainya. Namun seiring berjalannya waktu, saat ini perusahaan ini fokus hanya kepada jasa pembuatan kaos dan sablon.

Perusahaan ini didirikan pada tahun 2013 oleh dua usahawan muda dengan latar belakang pendidikan yang berbeda tapi mempunyai tujuan dan pemikiran yang sama dalam pengembangan usaha dibidang ini ke arah yang lebih besar. Brand atau merk yang diperkenalkan kepada masyarakat saat ini dikenal dengan nama Kaosdisablon yang merupakan salah satu strategi dalam pemasaran agar mudah dikenal dan diingat oleh orang.

Kaosdisablon sendiri merupakan kependekan dari Kaos Digital Sablon. Namun selain itu nama tersebut juga memiliki makna yang sebenarnya yaitu kaos yang disablon. Pelayanan yang diberikan selain menerima pemesanan kaos quantity partai besar kaosdisablon juga menerima pemesanan dalam quantity kecil (satuan). Selain itu kaosdisablon juga menerima jasa desain dan setting gambar. Saat ini kaosdisablon menyediakan stok kaos polos dengan berbagai varian jenis bentuk dan banyak warna. Untuk varian jenis kaos diantaranya:

a. T-shirt (Lengan Pendek) 
b. Longsleeve (Lengan Panjang)

c. Polo Shirt

d. Raglan (Lengan 3/4)

e. Hoodie, dsb.

Dengan varian warna seperti: hitam, putih, navy, biru, merah, kuning, hijau, abu, dsb.

CV. Purwa Satya atau Kaosdisablon menekankan suatu rancangan atau upaya untuk membangun hubungan dan promosi produk. Menjalin hubungan secara personal dengan konsumen dengan cara mendengar keluhan atau saran akan membuat konsumen lebih merasa dihargai. Pada akhirnya akan memberikan nilai tambah terhadap perkembangan bisnis terutama brand. Begitu pula dengan promosi, Kaosdisablon sangat memanfaatakan teknologi sebagai salah satu cara untuk meningkatkan penjualan.

Memasarkan produk secara online di berbagai media sosial, website, aplikasi maupun marketplace menjadi salah satu strategi yang diterapkan pada CV. Purwa Satya.

Media sosial Instagram menjadi salah satu media komunikasi pemasaran yang sangat berpengaruh terhadap penjualan produk Kaosdisablon. Setiap pemasaran perlu menyusun sebuah strategi pemasaran yang efektif dengan mengkombinasikan beberapa elemen-elemen dalam bauran pemasaran. Strategi pemasaran juga memerlukan keputusan-keputusan dari manajeman bauran pemasaran dalam bidang perencanaan produk, penetapan harga, saluran distribusi, serta promosi. Keempat bauran pemasaran ini saling berhubungan dan saling berpengaruh satu sama lain sehingga harus diupayakan untuk menghasilkan suatu kebijakan pemasaran yang mengarah pada kepuasan konsumen.

Kaosdisablon menggunakan teori 4P sebagai komunikasi pemasaran. Sebab pada aktivitas promosinya meliputi hal-hal seperti diatas. Dasar dari setiap bauran dilakukan oleh Kaosdisablon untuk mengembangkan brand dan produk dilihat dari keberhasilan Kaosdisablon memanfaatkan Instagram sebagai sebuah media pemasaran online.

\section{Produk}

Setiap produk Kaosdisablon yang ada akan di posting di Instagram dengan beberapa keterangan bahan, ukuran, dan warna. Akun Instagram sebagai sebuah katalog produk yang ditawarkan. Inovasi yang dibuat oleh kaosdisablon juga ada dalam jenis sablonnya. Untuk jenis sablon konvensional atau manual kaosdisablon menawarkan jenis sablon plastisol. Untuk jenis sablon digital kaosdisablon menawarkan sablon polyflex dengan varian seperti:
a. PVC
b. PU
c. Flock (beludru)
d. Glitter
e. Glow in the dark
f. Reflective
g. Foil, dsb.

Saat ini untuk produksi kaos, kaosdisablon masih bekerja sama dengan beberapa vendor koveksi yang terbaik. Seiring berkembangnya perusahaan, saat ini kaosdisablon memiliki 4 karyawan yang terdiri dari bagian finance, marketing, produksi dan desain. Kaosdisablon juga membuka peluang kepada masyarakat umum untuk bekerja sama dalam penjualan produknya. Saat ini kaosdisablon memiliki lebih dari 10 reseller. Yang menjadi nilai lebih dari kaosdisablon yaitu selalu memberikan pelayanan terbaik terhadap customer dan reseller, termasuk juga selalu menjaga kualitas dari bahan dan jahitannya serta memberikan garansi terhadap produk yang dibuat.

Workshop dan store kaosdisablon berada di Jalan KNPI No.22 yang cukup strategis dekat dari jalan utama. Strategi pemasaran yang dilakukan kaosdisablon selain konvensional atau offline kaosdisablon juga sangat konsen dalam pemasaran online. Kaosdisablon memiliki website utama dengan alamat: www.kaosdisablon.com.

CV. Purwa Satya atau Kaosdisablon memanfaatkan instagram, facebook, aplikasi, website dan marketplace lainnya sebagai komunikasi pemasaran media online, namun demikian Kaosdisablon lebih sering menggunakan instagram dibandingkan dengan facebook dan marketplace lainnya. Dalam wawancara pemilik CV. Purwa Satya mengatakan: "menurut saya, saat ini Instagram memang sangat potensial ya, karena dari sisi pengguna sekarang kita ketahui bahwa Instagram dan Facebook sangat besar. Tetapi, ya Instagram sih yang sampai saat ini berpengaruh bagi Kaosdisablon".

Pemilihan media ini tentu saja tanpa adanya alasan khusus atau jelas akan tetapi sebagaimana yang kita ketahui bahwa dalam berbagi foto Instagram jauh lebih terfokus dibandingkan media sosial lainnya. Tidak seperti facebook dan platform digital marketing lainnya, Instagram memang dirancang khusus untuk berbagi foto saja. Sementara media sosial lain, walaupun juga telah menyediakan fitur tersebut namun terdapat fitur lain yang menjadi unggulan keduanya seperti teks (update status).

Inilah yang menjadikan Instagram sebagai pemasaran media online yang paling tepat karena terfokus pada gambar yang akan dipromosikan. Selain itu, instagram bisa mengsingkronkan akun facebook dan twitter, jadi ketika Kaosdisablon mengupload foto jualannya pada instagram maka dengan fitur yang tersedia secara otomatis juga dapat langsung terupload pada facebook dan twitter, jadi Kaosdisablon tidak perlu lagi untuk mengupload berulang-ulang pada media lain, sementara sebaliknya kedua media tersebut ini, tidak memiliki fitur yang sama ke instagram. Sehingga ini menjadi motivasi saya untuk memasarkan dan beriklan disana, karena sudah pasti kita mengiklan itu mencari pasar yang memang besar kan.."

Seperti yang telah diketahui bahwa pengguna Instagram di Indonesia semakin banyak 
hingga saat ini. Dimana penggunanya bukan hanya pada kalangan remaja tetapi hampir semua kalangan menggunakannya. Ini tentu saja menjadi lahan yang menguntungkan bagi para pembisnis online shop khususnya Kaosdisablon untuk memasarkan produknya melalui Instagram.

Selain memiliki fungsi sebagai sosial media, Instagram di dukung dengan beberapa fitur. Sehingga dengan fitur yang ada tersebut, akan mampu membuat followers atau pengikut mudah untuk memilah apa yang sedang dicarinya. Konten foto atau video, caption serta hastag mejadi hal yang diperhatiakan oleh Kaosdisablon. Dalam wawancara pemilik mengatakan: "Biasanya kita menampilkan produk-produk yang sudah kita buat, kemudian kita juga menampilkan promo-promo seperti gratis ongkir, kemudian promo beli 2 gratis 1 dan lain sebagainya."

"Captionnya sih kita tidak muluk-muluk ya, kita biasanya menerangkan mengenai produk itu tersendiri, kemudian kita menerangkan mengenai harga dari produknya, dan dari ketersediaan stok nya"

“... apalagi jika di Instagram menggunakan hastag, itu juga berpengaruh. Ketika kita menggunakan hastag yang berkaitan dengan produk yang kita tampilkan, biasanya respon dari pengguna Instagram itu lebih banyak"

Komunikasi pemasaran di Instagram juga memiliki kelebihan dari tingkat penyebaran pemasaran yang luas. Kaosdisablon juga bekerja sama dalam hal promosi dengan salah satu bisnis jasa pengiriman dengan mengiklan di media sosial serta katalog milik jasa pengiriman tersebut. Dengan jasa inilah Instagram Kaosdisablon semakin diketahui oleh orang banyak.

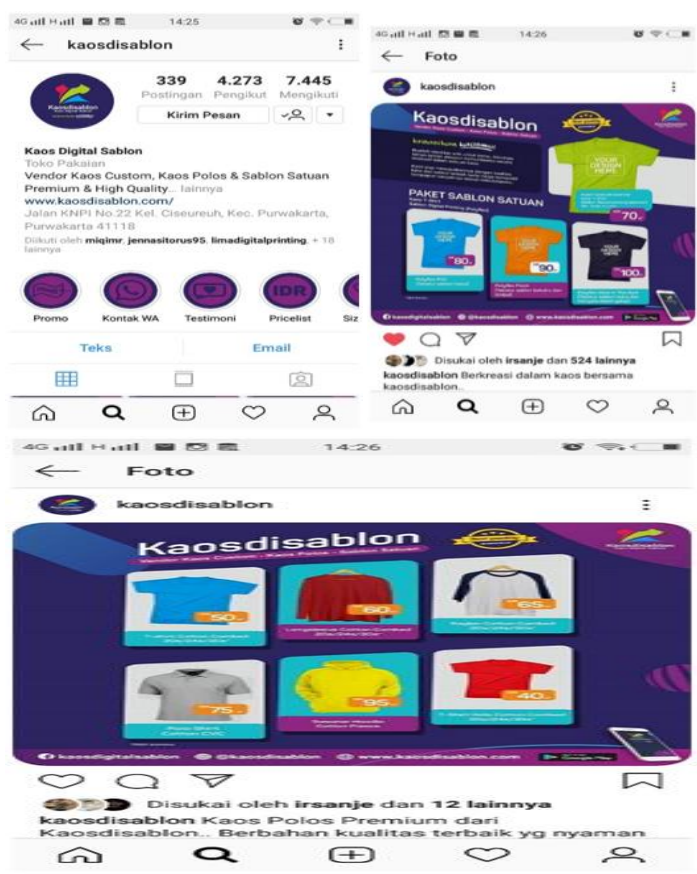

Gambar 2. Bentuk pemasaran Instagram Kaosdisablon (CV. Purwa Satya, 2019)
Pemanfaatan instagram sebagai media komunikasi pemasaran memiliki dampak positif dan negatif. Dalam melakukan bisnis online, dampak yang dirasakan oleh Owner dan Admin Kaosdisablon lebih ke arah positif.

Pembeli langsung dari Instagram lebih unggul dari pembeli yang berasal dari facebook dan yang mendatangi store atau toko secara langsung. Meskipun terlihat persaingan yang lumayan ketat antara pembeli langsung dari Instagram dan yang mendatangi toko secara langsung, tetapi sebagian besar yang mendatangi toko secara langsung, mengetahui informasi tentang Kaosdisablon dari media sosial Instagram.

Tabel 1. Presentase Data

Pembeli Kaosdisablon (2019)

\begin{tabular}{lll}
\hline Pembeli & Jumlah & $(\%)$ \\
\hline Instagram & 394 & 54.72 \\
Facebook & 32 & 4.44 \\
Pengunjung Langsung & 294 & 40.83 \\
Total & 720 & 100 \\
\hline
\end{tabular}

Pada Tabel 1 dan Gambar 3 menunjukkan bahwa pembeli langsung dari Instagram lebih unggul dari pembeli yang berasal dari facebook dan yang mendatangi store atau toko secara langsung. Meskipun terlihat persaingan yang lumayan ketat antara pembeli langsung dari Instagram dan yang mendatangi toko secara langsung, tetapi sebagian besar yang mendatangi toko secara langsung, mengetahui informasi tentang Kaosdisablon dari media sosial Instagram.

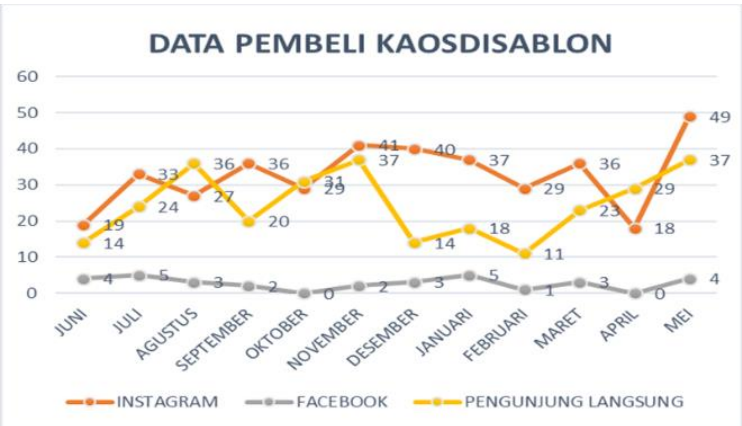

Gambar 3. Data Pembeli Kaosdisablon dari periode Juni 2018-Mei 2019 (CV. Purwa Satya, 2019)

Menurut pegawai/admin @ kaosdisablon: "Kalau menurut saya dampak Instagram bagi penjualan itu ya sangat bagus, soalnya banyak yang melakukan order kesini itu bukan karena dia tau tempatnya dimana, tapi dia tau informasi itu melalui media sosial Instagram. Dan kebanyakan yang melakukan order disini itu melalui sosial media, jadi pertamanya mereka chat dulu di sosial media, setelah itu kita kasih kontak, kemudian dia melakukan order. Jadi dampaknya kalau menurut saya sangat bagus kalau dari Instagram.” 
Pada Tabel 2 dapat dilihat bahwa para customer atau pembeli Kaosdisablon memperoleh informasi pertama kali dari sosial media Instagram sebanyak $88,47 \%$ lebih besar dibanding dengan informasi lain-lain yang berasal dari facebook, mulut ke mulut ataupun yang mendatangi toko secara langsung dengan jumlah $11,53 \%$.

Tabel 2. Presentase Data Informasi Pembeli

\begin{tabular}{lll}
\hline Sumber Informasi & Jumlah & $(\%)$ \\
\hline Info dari Instagram & 637 & 88.47 \\
Info dari lain-lain & 83 & 11.53 \\
Total & 720 & 100 \\
\hline
\end{tabular}

Dengan adanya informasi secara lengkap pada akun Instagram Kaosdisablon memudahkan para customer untuk berbelanja atau membeli produk yang diinginkan tanpa harus mendatangi toko secara langsung. Tabel 3 menunjukkan bahwa yang melakukan pembelian secara online yang mengetahui informasi langsung dari Instagram yaitu sebanyak $85,87 \%$, lebih unggul dari pada yang mendatangi toko secara langsung yang juga mendapatkan informasi dari Instagram sebanyak $14,13 \%$.

Tabel 3. Presentase Data Pembeli Berdasarkan Informasi dari Instagram

\begin{tabular}{lll}
\hline Jenis Transaksi & Jumlah & $(\%)$ \\
\hline Beli Online & 547 & 85.87 \\
Beli Langsung & 90 & 14.13 \\
Total & 637 & 100 \\
\hline
\end{tabular}

Dampak positif Instagram ini tidak hanya dirsakan oleh pemilik dan karyawan Kaosdisablon saja, tetapi juga para customer serta reseller merasakan hal yang sama seperti: sangat memudahkan, bisa jadi referensi dan untuk mengetahui promo-promo apa aja yang ada di Kaosdisablon.

Selain dampak positif, Instagram juga memiliki beberapa dampak negatif dalam pemasaran barang. Antara lain karena banyaknya kuota yang digunakan saat memakai atau mengoperasikan Instagram, tidak adanya hak cipta foto atau keamanan agar foto tidak diambil orang secara semana-mena, dan memerlukan waktu yang cukup lama untuk perencanaan di pemasaran atau promosi di Instagram agar barang kita di Instagram kita tetap diminati banyak orang serta tidak semua kalangan umur memakai Instagram, contoh saja untuk kalangan dewasa atau ibu-ibu yang jarang menggunakan instagram sebagai sarana jual beli. Seperti hasil wawancara dengan pemilik Kaosdisablon: "Cuma kekurangannya ya mungkin di kalangan orang tua itu banyak juga yang belum memiliki akun Instagram." Tetapi berbeda halnya dengan customer serta reseller mengenai dampak negatifnya yang belum ada sejauh ini. Berdasarkan hasil wawancara yang sudah dilakukan oleh peneliti rata-rata yang mereka rasakan adalah manfaat serta dampak positifnya karena instagram sangat memudahkan dalam mencari informasi dan dalam melakukan proses pembelian produk Kaosdisablon.

\section{Kesimpulan}

Kaosdisablon memanfaatkan instagram sebagai media pemasaran online-nya dengan menentukan tujuan komunikasi pemasaran melalui model komunikasi pemasaran modern, memanfaatkan fitur yang ada di Instagram, serta mengenali sifat konsumen untuk pemeliharaan media pemasaran yang tepat. Secara keseluruhan, Kaosdisablon memanfaatkan instagram sebagai media komunikasi pemasaran online-nya sesuai dengan beberapa feature yang ada pada Instagram. Kaosdisablon juga memanfaatkan feature terbaru Instagram yaitu dengan mengubah ke akun bisnis untuk memfokuskan target dan rutin memanfaatkan feature iklan setiap hari. $88,47 \%$ pembeli mengetahui informasi kaosdisablon dari Instagram, hal tersebut terjadi karena Instagram memudahkan para customer Kaosdisablon untuk mengetahui informasi-informasi menarik dan dalam melakukan proses pembelian produk Kaosdisablon.

\section{Daftar Pustaka}

Jefkins, Frank. 1997. Periklanan. Jakarta: Erlangga.

Kennedy, John E. dan R. Soemanagara. 2006. Marketing Communication. Jakarta: PT. Buana Ilmu Populer,

Morissan, M.A. 2010. Periklanan Komunikasi Pemasaran Terpadu. Jakarta: Kencana Prenada Media Group.

Priansa, Donni Juni. 2017. Komunikasi Pemasaran Terpadu pada Era Media Sosial. Bandung: Pustaka Setia.

Purba, Amir et. al. 2006. Pengantar Ilmu Komunikasi. Medan: Pustaka Bangsa Press,

Sa'diya, Lailatus. 2017. Strategi Promosi Di Media Sosial Instagram Terhadap Kesadaran Merek Di Era Generasi Z. Journal Trunojoyo, Vol 11, No 2.

Setiadi, J. Nugroho. 2008. Perilaku Konsumen: Konsep dan Implikasi Untuk Strategi Pemasaran. Jakarta: Prenada Media Grup.

Sulianta, Feri. 2015. Keajaiban Sosial Media Fantastis Menumbuhkan Visitor, Circle, Likes, Koneksi, Retweet, dan Follwers. Jakarta: PT. Elex Media Komputindo.

Sutisna. 2001. Prilaku Konsumen dan Komunikasi Pemasaran. Bandung: PT. Remaja Rosdakarya. 